\title{
PENDIDIKAN KARAKTER RASA INGIN TAHU MELALUI PEMBELAJARAN KONSTRUKTIF DALAM KISAH MUSA DAN KHIDIR
}

\author{
Lukmanul Hakim*, Ismail Marzuki** \\ lukman@umt.ac.id, ismailmarzuki@umt.ac.id \\ * Dosen Fakultas Agama Islam, Universitas Muhammadiyah Tangerang \\ **Dosen Fakultas Agama Islam, Universitas Muhammadiyah Tangerang
}

\begin{abstract}
A developed nation is a nation that values education and science. Because without these two things, it is difficult for a nation to wake up or survive the various challenges that have plagued the existence of a nation. Culture of studying is a must-have aspect, so that education and science that are expected to strengthen the existence of a nation can be achieved. To achieve a culture of studying, many components must be nurtured. By making the process of studying science a culture of national character, it is hoped that the phenomenon of civilization distortion can be addressed by the proficiency of knowledge and skills in various lines of life. The Indonesian people seem to have begun to realize the context of this problem. This can be seen with the inclusion of curiosity to be one of the target components for the achievement of the nation's character. In the implementation of curiosity character education becomes its own challenge so that this character can be well embedded. Constructive learning originating from the philosophy of constructiveism seeks to connect and refine the points of knowledge stored within an object of education, so as to form a motivational construction originating from oneself to always be uplifted in search of projected knowledge in accordance with desired ideals. The Koran, which contains many educational concepts, turns out in advance to give an example of how the implementation of constructive learning is carried out. Is the story between the Prophet Musa and the Prophet Kheer explaining the concept of constructivism learning. In his story the character of Moses' curiosity was honed by the education provided by the Prophet Khidir through constructiveism learning methods.
\end{abstract}

Keywords: Constructive learning, Character, Curiosity.

\section{A. PENDAHULUAN}

Hakikat manusia sebagai makhluk yang berbudaya merupakan ciri yang membedakan dengan makhluk lain. Sebagaimana dikatakan oleh Ralph Linton sebagaimana dikutip oleh tasmuji mengatakan bahwa; kebudayaan adalah seluruh cara kehidupan dari masyarakat dan tidak hanya mengenai sebagian tata cara hidup saja yang dianggap lebih tinggi dan lebih diinginkan. ${ }^{1}$ Cara hidup manusia terus berkambang dan berubah dari masa ke masa.

Perubahan ini terlihat dalam sejarah perkembangan ilmu pengetahuan. Manusia tidak berhenti pada kepercayaan animisme, dinamisme, akan tetapi berkembang pada filsafat, rasionalisme, logika, ilmu pengetahuan dan science. Walau pun dalam perjalannya penuh dengan hiruk pikuk dan

\footnotetext{
${ }^{1}$ Tasmuji, Dkk, Ilmu Alamiah Dasar, Ilmu Sosial Dasar, Ilmu Budaya Dasar, (Surabaya: IAIN Sunan Ampel Press, 2011), hal 151.
} 
tantangan, tapi perubahan ini tak bisa dibendung oleh otoretarianisme tradisi teokrasi yang menentang potensi progresifisme manusia. Tampak perubahan dalam sejarah manusia, dari makhluk primitif menjadi manusia modern yang berperadaban.

Distrupsi perubahan peradaban manusia tak lepas dari naluri manusia yang terus mengambangkan pengetahuan. Rasa ingin tahu merupakan karakter yang dimiliki manusia. Karakter ini mendorong manusia tanpa henti terus mengembangkan ilmu pengetahuan dan peradabannya. Tanpa mengikuti arus perkembangan jaman, maka manusia akan tertinggal, dan tergilas jaman.

Namun demikian, ditinjau dari framework agama islam. Agama islam, selain mendorong umatnya untuk menjelajahi samudera ilmu pengetahuan, juga memberikan bimbingan dan batas batas dalam mengembangkan karakter rasa ingin tahu. Sehingga hasil dari penalaran, penelitian menghasilkan ilmu pengetahuan dan peradaban yang selaras dengan agama dan kemaslahatan umat manusia.

Dalam kisah Musa dan Khidir, akan tampak bahwa manusia selalu perlu untuk melakukan pembelajaran, tidak cukup dengan ilmu pengetahuan yang dimiliki. Demikian juga tidak bisa memberikan kesimpulan terhadap suatu masalah hanya dengan menggunakan premis dan konklusi yang berasal dari penalaran individual personal, akan tetapi diperlukan masukan dan bimbingan dari elemen external, baik berupa mentor, atau guru yang memiliki kapasistas keilmuan dan wawasan yang lebih mumpuni. Dalam proses penelusuran tanpa henti ini memerlukan energi yang kuat. Energi ini salah satunya adalah karakter rasa ingin tahu. Dengan memiliki karakter rasa ingin tahu yang tinggi, pengetahuan lama akan terus dikonstruk dengan ilmu dan pengetahuan baru yang didapatkan dalam proses pembelajaran.

\section{B. PEMBAHASAN}

\section{Pendidikan}

Dalam Kamus Besar Bahasa Indonesia, Pendidikan berasal dari dua suku kata yaitu " $d i$ " dan "dik". Lalu kata ini mendapat awalan kata "pe" dan akhiran "an" sehingga menjadi "pendidikan". Artinya "proses pengubahan sikap dan tata laku seseorang atau kelompok orang dalam usaha mendewasakan manusia melalui upaya pengajaran dan pelatihan. proses, cara, perbuatan mendidik."

Pendidikan dikenal juga dengan istilah pedagogie. Menurut Abu Ahmadi dan Nur Uhbiyati, istilah ini berasal dari bahasa Yunani. Paedagogike adalah kata majemuk yang terdiri dari kata "paes" yang berarti "anak" dan kata "Ago" yang berarti "aku membimbing." Jadi Pedagogike berarti aku membimbing anak. Orang yang memiliki pekerjaan membimbing anak dengan maksud membawanya ke tempat belajar, dalam bahasa Yunani disebut "Pedagogos." Menurut Abu Ahmadi dan Nur Uhbiyati, jika kata ini diartikan secara simbolis, maka perbuatan membimbing seperti di atas itu, merupakan inti perbuatan mendidik yang tugasnya hanya untuk membimbing saja, dan kemudian pada suatu saat harus melepaskan anak itu kembali ke masyarakat. ${ }^{3}$

Menurut McLeod, sebagaimana dikutip oleh Muhibbin Syah, dalam bahasa Inggris, education (pendidikan) berasal dari kata educate (mendidik) artinya memberi peningkatan (to elicit, to give rise to), dan mengembangkan (to evolve, to develop). Dalam pengertian yang sempit, education atau pendidikan berarti perbuatan atau proses perbuatan untuk memperoleh pengetahuan. ${ }^{4}$

2 Pusat Bahasa Departemen Pendidikan Nasional, KBBI (Kamus Besar Bahasa Indonesia), h. 330 .

Abu Ahmadi dan Nur Uhbiyati, Ilmu Pendidikan, (Jakarta: PT Rineka Cipta, 2003), Cet. ke-2, h. 70.

4 Muhibbin Syah, Psikologi Pendidikan, (Bandung: Remaja Rosdakarya, 1995), Cet. ke-2, h. 10 . 
Menurut John Dewey sebagaimana dikutip oleh Yunus, pendidikan adalah suatu proses pembaharuan makna pengalaman, hal ini mungkin terjadi dalam pergaulan biasa atau pergaulan orang dewasa dengan orang muda, mungkin pula terjadi secara sengaja dan dilembagakan untuk menghasilkan kesinambungan sosial. Proses ini melibatkan pengawasan dan perkembangan dari orang yang belum dewasa dan kelompok dimana ia hidup. ${ }^{5}$

\section{Karakter Rasa Ingin Tahu}

Karakter berasal dari bahasa Yunani kharakter yang berakar dari diksi 'kharassein' yang berarti memahat atau mengukir (to incribe/to engrave), sedang dalam bahasa Latin, karakter bermakna membedakan tanda. ${ }^{6}$ Dalam kamus InggrisIndonesia, John M. Echols dan Hassan Shadily menyebutkan bahwa karakter berasal dari bahasa Inggris yaitu character yang berarti watak, karakter atau sifat. ${ }^{7}$

E. Mulyasa dalam bukunya Manajemen Pendidikan Karakter mengutip Edward Wynne sebagai berikut: Karakter berasal dari Bahasa Yunani yang berarti "to mark" (menandai) dan memfokuskan pada bagaimana menerapkan nilai-nilai kebaikan dalam tindakan nyata atau perilaku seharihari. Oleh sebab itu, seseorang yang berperilaku tidak jujur, curang, kejam dan rakus dikatakan sebagai orang yang memiliki karakter jelek, sedangkan yang berperilaku baik, jujur, dan suka menolong dikatakan sebagai orang yang memiliki karakter baik/mulia. ${ }^{8}$

Doni Koesoema mengutip Sjarkawi, menyatakan bahwa karakter juga sering diasosiasikan dengan istilah apa yang disebut dengan temperamen yang lebih memberi penekanan pada definisi psikososial

${ }^{5}$ Yunus, Filsafat Pendidikan, (Bandung: Citra Sarana Grafika, 1999), h. 7.

6 Sri Narwanti, Pendidikan Karakter, (Yogyakarta: Familia, 2011), Cet. ke. I, h. 1.

John M. Echols dan Hassan Shadly, Kamus Inggris-Indonesia, (Jakarta: PT. Gramedia, 2006), h. 107.

8 H. E. Mulyasa, Manajemen Pendidikan Karakter, (Jakarta: Bumi Aksara, 2011), Cet. Ke-I, h. 3 (pemahaman seorang individu atas situasi sosial di lingkungannya) yang dihubungkan dengan pendidikan dan konteks lingkungan. Sedangkan karakter dilihat dari sudut pandang behaviorial lebih menekankan pada unsur somatopsikis (penyakit fisik yang disebabkan oleh kejiwaan) yang dimiliki seseorang sejak lahir. ${ }^{9}$

Elfindri dkk mengartikan karakter sebagai sifat-sifat kejiwaan, akhlak, atau budi pekerti yang membedakan seseorang dengan orang lain. ${ }^{10}$ Kemudian Elfindri dkk mengklasifikasikan karakter pada empat bagian; karakter lemah, karakter kuat, karakter jelek dan karakter baik. Masingmasing dapat dilihat dengan indikator karakter sebagai berikut: ${ }^{11}$

1. Karakter lemah dapat ditemukan seperti; penakut, tidak berani mengambil resiko, pemalas, cepat kalah, dan beberapa jenis lainnya.

2. Karakter kuat dapat ditemukan seperti; tangguh, ulet, mempunyai daya juang yang kuat serta pantang mengalah.

3. Karakter jelek, misalnya; licik, egois, serakah, sombong, tinggi hati, pamer, suka ambil muka, dan sebagainya.

4. Karakter baik, misalnya; jujur, terpercaya, rendah hati, amanah dan sebagainya.

Dengan melihat klasifikasi dan indikator di atas, Elfindri dkk menyimpulkan bahwa karakter anak yang diharapkan adalah karakter yang kuat dan baik. Kualitas mental atau kekuatan moral, akhlak atau budi pekerti yang merupakan kepribadian khusus yang harus melekat. ${ }^{12}$

Upaya penguatan karakter yang dicetuskan oleh pemerintah diwujudkan dengan pengembangan 18 karakter budaya bangsa. Karakter tersebut adalah "(1) Religius, (2) Jujur, (3) Toleransi, (4) Disiplin, (5) Kerja Keras, (6) Kreatif, (7) Mandiri, (8) Demokratis, (9) Rasa Ingin Tahu, (10) Semangat Kebangsaan, (11)

9 Doni Koesoema A, Pendidik Karakter Strategi Mendidik Anak di Zaman Global, (Jakarta: Grasindo, 2007), Cet. ke-1, h. 80.

${ }^{10}$ Elfindri dkk, Pendidikan Karakter Kerangka, Metode, dan Aplikasi untuk Pendidik dan Profesional, (Jakarta: Baduose Media, 2012), Cet. ke-I, h. 27.

$$
\begin{aligned}
& { }^{11} \text { Ibid., h. } 28 . \\
& { }^{12} \text { Ibid., h. } 28 .
\end{aligned}
$$


Cinta Tanah Air, (12) Menghargai Prestasi, (13) Bersahabat atau Komunikatif, (14) Cinta Damai, (15) Gemar Membaca, (16) Peduli Lingkungan, (17) Peduli Sosial, (18) Tanggung-jawab. Delapan belas karakter budaya bangsa wajib dikembangkan. Salah satu diantara delapan belas karakter bangsa ini adalah rasa ingin tahu.

\section{Pengertian Sikap Rasa Ingin Tahu}

Rasa ingin tahu senantiasa akan memotivasi diri untuk terus mencari dan mengetahui hal-hal yang baru sehingga akan memperbanyak ilmu pengetahuan dan pengalaman dalam kegiatan belajar. Hal ini di dukung juga menurut Samani, dkk ${ }^{13}$ "rasa ingin tahu (curiosity) merupakan "keinginan untuk menyelidiki dan mencari pemahaman terhadap rahasia alam". Sedangkan menurut Mustari ${ }^{14}$ "rasa ingin tahu yaitu sikap dan tindakan yang selalu berupaya untuk mengetahui lebih mendalam dan meluas dari apa yang dipelajarinya, dilihat dan didengar". Hal ini berkaitan dengan kewajiban terhadap diri sendiri dan alam lingkungan.

Olah hati berkenaan dengan perasaan, sikap dan keyakinan atau keimanan serta berkenaan dengan proses nalar guna mencari dan menggunakan pengetahuan secara kritis, kreatif dan inovatif. Hal ini selaras dengan pengertian rasa ingin tahu menurut Mustari ${ }^{15}$ "kuriositas atau rasa ingin tahu adalah emosi yang dihubungkan dengan perilaku mengorek secara alamiah seperti eksplorasi, investigasi dan belajar". Menurut Samani, dkk ${ }^{16}$ "karakter individu secara psikologis dimaknai sebagai hasil keterpaduan dari empat bagian yakni olah hati, olah pikir, olahraga, olah rasa dan karsa". Olah rasa dan karsa berkenaan

${ }^{13}$ Samani, dkk (2012, hlm. 104) Konsep dan Model Pendidikan Karakter. Bandung: PT. Rosdakarya.

14 Mustari (2011, hlm.103) Nilai Karakter: Refleksi untuk Pendidikan Karakter. Yogyakarta: Laksbang Pressindo.

15 Mustari (2011, hlm.104) Nilai Karakter: Refleksi untuk Pendidikan Karakter. Yogyakarta: Laksbang Pressindo.

16 Samani, dkk (2012, hlm. 24) Konsep dan Model Pendidikan Karakter. Bandung: PT. Rosdakarya. dengan kemauan, motivasi dan kreativitas yang tercermin dalam kepedulian, citra dan penciptaan kebaruan.Rasa ingin tahu merupakan karakter yang bersumber dari olah pikir.

Rasa ingin tahu membuat siswa lebih peka dalam mengamati berbagai fenomena atau kejadian di sekitarnya serta akan membuka dunia-dunia baru yang menantang dan menarik siswa untuk mempelajarinya lebih dalam. Hal yang menarik sangat banyak di dunia ini, tetapi seringkali karena rasa ingin tahu yang rendah, menyebabkan mereka melewatkan hal-hal yang menarik tersebut untuk dipelajari. Dengan adanya rasa ingin tahu dapat mengatasi rasa bosan siswa untuk belajar. Jika jiwasiswa dipenuhi dengan rasa ingin tahu akan sesuatu hal, maka mereka dengan sukarela dan antusias akan mempelajarinya. Sehingga, menjadikan rasa ingin tahu dalam diri siswa perlu dibangun dan dikembangkan. Pengertian rasa ingin tahu dari beberapa pendapat para ahli di atas dapat disimpulkan bahwa rasa ingin tahu adalah suatu rasaatau kehendak yang ada dalam diri manusia yang mendorong atau memotivasi manusia tersebut untuk berkeinginan mengetahui hal-hal yang baru, memperdalam dan memperluas pengetahuan yang dimiliki dengan perilaku mengorek secara alamiah seperti eksplorasi,investigasi dan belajar.

2. Faktor-faktor Yang Mempengaruhi Sikap Rasa Ingin Tahu

Faktor untuk mengembangkan rasa ingin tahu pada anak menurut Mustari ${ }^{17}$ sebagai berikut:

a. Kebebasan si anak itu sendiri harus ada untuk melakukan dan melayani rasa ingin tahunya.

b. Yang lebih baik adalah kita berikan kepada mereka cara - cara untuk mencari jawaban. Misalnya, apaila pertanyaan tentang bahasa inggris, berilah kepada anak itu kamus, apabila pertanyaan tentang pengetahuan, berilah

17 Mustari (2011, hlm.109) Nilai Karakter: Refleksi untuk Pendidikan Karakter. Yogyakarta: Laksbang Pressindo. 
mereka ensiklopedia, dan begitu seterusnya.

Selanjutnya menurut Sunaryo Karta Dinata $^{18}$ "menyebutkan beberapa gejala yang berhubungan dengan permasalahan rasa ingin tahuyang perlu mendapat perhatian dunia pendidikan", yaitu:

1) Ketergantungan disiplin kepada control luar dan bukan karena niat sendiri yang iklas. Prilaku seperti ini akan mengarah pada perilaku formalistik, aktulistik dan tidak konsisten, yang pada gilirannya akan menghambat pembentukan etos kerja dan etos kehidupan yang mapan sebagai salah satu cirri dari kualitas sumber daya dan rasa ingin tahu manusia.

2) Sikap kurangnya bertanya tentang suatu masalah.manusia yang pandai dan berhasil adalah bukanlah manusia yang diam saja, dan menunggu hasil jawaban, atau ditanya orang lain, melainkan manusia yang pandai dan berhasil adalah manusia yang mempunyai rasa ingin tahu yang tinggi dengan banyaknya bertanya terhadap suatu permasalahan.

Dari pendapat di atas maka dapat disimpulkan bahwa faktor - faktor yang mempengaruhi sikap rasa ingin tahu siswa adalah: yang pertama,faktor dirumah yaini cara orang tua mendidik anaknya. Kedua, faktor lingkungan sekolah yaitu bagaimana pendidik mengajarkan bagaimana siswa menjadi anak yang mempunyai rasa ingin tahu yang tinggi. Ketiga, faktor lingkuangan masyarakat yaini bagaimana mendidik siswa mempunyai rasa ingin tahu yang tinggi dengan cara menghargai potensis peserta didik.

\section{Indikator Sikap Rasa Ingin Tahu}

Indikator rasa ingin tahu menurut Kemendiknas ${ }^{19}$ sebagai berikut:

18 Sunaryo Karta dinata (Desmita, hlm. 189) Psikologi Perkembangan Peserta Didik. Bandung: PT Remaja Rosdakarya.

19 KEMENDIKNAS (2010, hlm. 34) Pengembangan Pendidikan Budaya dan Karakter Bangsa. Pedoman Sekolah. Jakarta : Badan Penelitian dan Pengembangan Pusat Kurikulum.
1) Siswa cenderung bertanya selama pembelajaran jika ada hal yang tidak dipahami.

2) Membaca sumber di luar buku teks tentang materi yang terkait dengan materi pembelajaran.

3) Membaca atau menduskusikan gejala alam atau pembelajaran yang baru terjadi.

4) Bertanya tentang suatu yang terkait dengan materi pelajaran tetapi diluar yang di bahas di kelas.

Dari pendapat di atas maka dapat disimpulkan bahwa indikator sikap rasa ingin tahu yaitu siswa akan lebih sering bertanya selama proses pembelajaran, mencari sumber di luar buku teks, dan mendiskusikan pembelajaran yang terjadi.

\section{Pembelajaran Konstruktif}

Konsep 'pembelajaran' tidak sama persis dengan konsep 'belajar' meski keduanya mempunyai kaitan yang cukup erat. Belajar merupakan aktivitas subjek didik untuk mendapatkan informasi, pengetahuan dan pengalaman. Sedangkan pembelajaran merupakan aktivitas interaktif dan terstruktur antara pendidik dan peserta didik untuk mencapai suatu perubahan. Tentu saja perubahan yang diharapkan adalah perubahan yang lebih positif, bukan negatif.

Istilah pembelajaran sebenarnya digunakan untuk menegaskan bahwa interaksi belajar, terutama di kelas, antar pendidik dan peserta didik itu bersifat dinamis. Istilah ini juga sekaligus dimaksudkan untuk menyempurnakan istilah pengajaran yang lebih menekankan pada peran aktif pendidik semata, sedangkan peserta didik cenderung menerima begitu saja apa yang telah disampaikan oleh si pendidik. Pembelajaran sangat menekankan proses interaksi dan pemanfaatan sumber-sumber belajar secara optimal. $^{20}$

20 Muhamad Iksan, M. Sayuti, dkk. 2006. Pendidikan Kewarganegaraan Untuk SMTA, Majelis Pendidikan Dasar dan Menengah Pimpinan Pusat Muhammadiyah : Jakarta. hal : 7-8 


\section{Pendekatan}

konstruktivisme

merupakan proses pembelajaran yang menerangkan bagaimana pengetahuan disusun dalam pikiran siswa. Pengetahuan dikembangkan secara aktif oleh siswa sendiri dan tidak diterima secara pasif dari sekitarnya. Ini berarti pembelajaran merupakan hasil dari usaha siswa itu sendiri dan bukan dipindahkan dari guru kepada siswa. Yaitu tidak lagi berpegang pada konsep pengajaran dan pembelajaran yang lama, di mana guru hanya "menuang ilmu " kepada murid tanpa murid itu sendiri berusaha dan menggunakan pengalaman a tau pengetahuan mereka. ${ }^{21}$

Pada awal a bad 20 John Dewey menyatakan bahwa pendidik yang baik harus melaksanakan pembelajaran sebagai proses menyusun atau membina pengalaman secara terus menerus. Juga menekankan pentingnya keterlibatan aktif dati murid di dalam aktivitas pembelajaran. $^{22}$

Menurut

pandangan ahli konstruktivisme, setiap pembelajar mempunyai peranan dalam menentukan apa yang dipelajari. Ini berarti kepala siswa bukanlah kosong. Perhatian diberikan kepada siswa supaya berpeluang untuk membentuk konsep dan pengetahuan yaitu dengan mengaitkan pengalaman lampau dengan kegunaan masa depan. Di sini pembelajar melakukan proses mental yang lebih tinggi yaitu: berpikir, berimajinasi dan mencari penyelesaian masalah. ${ }^{23}$

Melalui pendekatan konstruktivisme, guru perlu mengubah peranannya dalam kelas. Berbeda dengan peran guru pada kelas direct instruction dalam pendekatan behaviorisme dimana guru mengkontrol semua kegiatan pembelajaran. Guru sebagai

21 Erman Suherman, dkk, Strategi Pembelajaran Matematika Kontemporer (Jurusan Pendidikan Matematika FPMIPA UPI, Bandung, 2003)h.74

${ }^{22}$ Robert E. Reys, et all, Helping Children Learn Mathematics (Allyn and Bacon, America, 1998),p.17

3 Leonard M. Kennedy, et all, Guiding Children's Learning of Mathematics (ThomsonWadsworth, USA, 2008) p. 49 sumber pengetahuan dan guru menjadi pusat kegiatan pembelajaran.

Adapun dalam pembelajaran konstruktivisme, yang menjadi pusat perhatian adalah siswa. Peran guru adalah sebagai fasilitator, terapis bahkan sebagai liberator (pembebas). ${ }^{24}$

Pembelajaran konstruktivisme dilakukan guru untuk memberi keleluasaan bagi peserta didik dalam memahami konsep yang dipelajari berorientasi pada pengalaman-pengalaman yang dimiliki peserta didik sebelumnya. Konstruktivisme (Constructivism) merupakan landasan berpikir (filosofi) pendekatan kontekstual. Pengetahuan dibangun oleh peserta didik melalui kegiatan eksplorasi dan diskusi dengan temannya. Pengetahuan bukanlah seperangkat fakta, konsep, atau kaidah yang siap untuk diambil dan diangkat. Tetapi peserta didik harus mengkonstruksi pengetahuan itu dan memberi makna melalui pengalaman nyata.

Pada dasarnya manusia dikaruniai kemampuan untuk mengkonstruksi atau membangun pengetahuan setelah ia berinteraksi dengan lingkungannya yaitu alam. $^{25}$ "Seseorang itu baru mengetahui sesuatu jika ia dapat menjelaskan unsurunsur apa yang membangun sesuatu itu., 26 Gagasan pokok inilah yang menjadi dasar dari konstruktivisme.

Piaget sebagaimana dikutip oleh Dahar mendefinisikan konstruktivisme sebagai suatu pandangan dimana suatu pengetahuan itu dibangun di dalam pikiran anak. $^{27}$ Berdasarkan pendapat tersebut dapat disimpulkan bahwa konstruktivisme merupakan sebuah model pembelajaran dengan menempatkan peserta didik sebagai agen aktif dalam proses belajar bermakna.

24 A Lefrancois and Guy R, Psychology for Teaching (Wadsworth Thomson Learing, USA,2000) p.203-204

25 Poedjiadi, Anna. 2010. Sains Teknologi Masyarakat: Metode Pembelajaran

Kontekstual Bermuatan Nilai, Bandung: Remaja Rosdakarya, hlm. 70

26 Suparno, Paul, Filsafat Konstruktivisme Dalam Pendidikan, Yogyakarta: Kanisius, 1997. hlm, 24.

27 Dahar, R. W. 1996. Teori-teori Belajar. Erlangga. Jakarta. hlm, 159 
Peserta didik tidak hanya menerima materi tapi juga menginterpretasikan materi. Dalam pendekatan konstruktivisme peserta didik dianggap telah mempunyai ide yang tersendiri tentang sesuatu konsep yang belum dipelajari, walaupun ide tersebut belum tentu benar.

Pengetahuan bukanlah seperangkat fakta-fakta, konsep atau kaidah yang siap untuk diambil dan diingat. Sehubungan dengan hal ini peserta didikpun tidak secara sederhana menerima saja informasi yang diberikan guru atau yang didapat dari buku teks, tetapi jika mereka tentang oleh sesuatu yang ingin mereka pelajari, untuk menghubungkan semua informasi yang sudah mereka miliki di dalam struktur kognitifnya dari pengalaman sebelumnya. Dengan perkataan lain mereka membangun pengetahuan baru dan menarik maknanya dengan jalan menghubungkan informasi baru dengan informasi yang sudah mereka miliki. "Esensi dari konstruktivisme adalah ide bahwa peserta didik harus menemukan dan mentransformasikan suatu inforamasi kompleks ke informasi lain, dan apabila dikehendaki informasi itu menjadi milik mereka sendiri." 28

Sebagai sebuah teori tentang bagaimana pengetahuan terbentuk, konstruktivisme mempunyai pandangan tertentu tentang pengetahuan. Secara garis besar ada tiga prinsip dasar yang merupakan inti pandangan konstruktivisme tentang pengetahuan. ${ }^{29}$

1. Pengetahuan merupakan hasil konstruksi manusia dan bukan sepenuhnya representasi suatu fenomena atau benda.

Fenomena atau obyek memang bersifat obyektif, namun observasi dan interpretasi terhadap suatu fenomena atau obyek terpengaruh oleh subyektivitas pengamat.

2. Pengetahuan merupakan hasil konstruksi sosial.

\footnotetext{
28 Sagala. 2003. Konsep dan Makna Pembelajaan. Alfabeta. Bandung. hlm, 88.

${ }^{29}$ Widodo, A. (2004). Constructivist Oriented Lessons: The learning environment and the teaching sequences. Frankfurt: Peter Lang.
}

Pengetahuan terbentuk dalam suatu konteks sosial tertentu. Oleh karena itu pengetahuan terpengaruh kekuatan sosial (ideologi, agama, politik, kepentingan suatu kelompok, dsb) dimana pengetahuan itu terbentuk.

3. Pengetahuan bersifat tentatif.

Sebagai konstruksi manusia, kebenaran pengetahuan tidaklah mutlak tetapi bersifat tentatif dan senantiasa berubah. Sejarah telah membuktikan bahwa sesuatu yang diyakini "benar" pada suatu masa ternyata "salah" di masa selanjutnya.

Sebagai konsekuensi dari ketiga prinsip dasar sebagaimana diuraikan di atas, konstruktivisme juga mempunyai pandangan tentang belajar dan mengajar.

Berdasarkan sejumlah literatur tentang konstruktivisme, Widodo mengidentifikasi lima hal penting berkaitan dengan belajar dan mengajar. ${ }^{30}$

1. Pembelajar telah memiliki pengetahuan awal.

Tidak ada pembelajar yang otaknya benar-benar kosong. Pengatahuan awal yang dimiliki pembelajar memainkan peran penting pada saat dia belajar tentang sesuatu hal yang ada kaitannya dengan apa yang telah diketahui.

2. Belajar merupakan proses pengkonstruksian suatu pengatahuan berdasarkan pengatahuan yang telah dimiliki.

Pengetahuan tidak dapat ditransfer dari suatu sumber ke penerima, namun pembelajar sendirilah yang mengkonstruk pengetahuan.

3. Belajar adalah perubahan konsepsi pembelajar.

Karena pembelajar telah memiliki pengetahuan awal, maka belajar adalah proses mengubah pengetahuan awal siswa sehingga sesuai dengan konsep yang diyakini "benar" atau agar pengetahuan awal siswa bisa

${ }^{30}$ Widodo, A. (2004). Constructivist Oriented Lessons: The learning environment and the teaching sequences. Frankfurt: Peter Lang. 
berkembang menjadi suatu konstruk pengetahuan yang lebih besar.

4. Proses pengkonstruksian pengetahuan berlangsung dalam suatu konteks sosial tertentu.

Sekalipun proses pengkonstruksian pengetahuan berlangsung dalam otak masing-masing individu, namun sosial memainkan peran penting dalam proses tersebut sebab individu tidak terpisah dari individu lainnya.

5. Pembelajar bertanggung jawab terhadap proses belajarnya.

Guru atau siapapun tidak dapat memaksa siswa untuk belajar sebab tidak ada seorangpun yang bisa "mengatur" proses berpikir orang lain. Guru hanyalah menyiapkan kondisi yang memungkinkan siswa belajar, namun apakah siswa benar-benar belajar tergantung sepenuhnya pada diri pembelajar itu sendiri. Literatur tentang pembelajaran yang berbasis konstruktivisme mengindikasikan bahwa pembelajaran yang konstruktivis memerlukan lingkungan pembelajaran yang konstruktivis dan juga tahapan pembelajaran yang konstruktivis.

Lingkungan pembelajaran yang dimaksud bukanlah hanya lingkungan fisik semata tetapi juga lingkungan sosial dan emosional. Berdasarkan sejumlah literatur tentang tahapan pembelajaran yang konstruktivis, ${ }^{31}$ Widodo menyatakan bahwa pembelajaran yang konstruktivis terdiri dari 5 tahapan yang saling berurutan, yaitu: ${ }^{32}$

1. Pendahuluan: Tahap penyiapan pembelajar untuk mengikuti kegiatan pembelajaran.

2. Eksplorasi: Tahap pengidentifikasian dan pengaktifan pengetahuan awal pembelajar.

${ }^{31}$ Driver, R. (1989). Changing conceptions. In P. Adey, J. Bliss, J. Head \& M. Shayer (Eds.), Adolescent Development and School Science (pp. 79-104). New York: The Falmer Press.

${ }^{32}$ Widodo, A. (2004). Constructivist Oriented Lessons: The learning environment and the teaching sequences. Frankfurt: Peter Lang.
3. Restrukturisasi: Tahap restrukturisasi pengetahuan awal pembelajar agar terbentuk konsep yang diharapkan.

4. Aplikasi: Tahap penerapan konsep yang telah dibangun pada konteks/kondisi yang berbeda ataupun dalam kehidupan seharihari.

5. Review dan Evaluasi: Tahap peninjauan kembali apa yang telah terjadi pada diri pembelajar berkaitan dengan suatu konsep/pembelajaran.

\section{Kisah dan Musan dan Khidir}

Kisah Nabi Khidir as dengan Nabi Musa as diceritakan dalam al-Quran Surat Al-Kahfi Ayat 60-82. Adapun terjemah ayat-ayat tersebut adalah sebagai berikut:

60. Dan (ingatlah) ketika Musa berkata kepada pembantunya, "Aku tidak akan berhenti (berjalan) sebelum sampai ke pertemuan dua laut; atau aku akan berjalan (terus sampai) bertahuntahun."

61. Maka ketika mereka sampai ke pertemuan dua laut itu, mereka lupa ikannya, lalu (ikan) itu melompat mengambil jalannya ke laut itu.

62. Maka ketika mereka telah melewati (tempat itu), Musa berkata kepada pembantunya, "Bawalah kemari makanan kita; sungguh kita telah merasa letih karena perjalanan kita ini."

63. Dia (pembantunya) menjawab, "Tahukah engkau ketika kita mencari tempat berlindung di batu tadi, maka aku lupa (menceritakan tentang) ikan itu dan tidak ada yang membuat aku lupa untuk mengingatnya kecuali setan, dan (ikan) itu mengambil jalannya ke laut dengan cara yang aneh sekali."

64. Dia (Musa) berkata, "Itulah (tempat) yang kita cari." Lalu keduanya kembali, mengikuti jejak mereka semula. 
65. Lalu mereka berdua bertemu dengan seorang hamba di antara hamba-hamba Kami, yang telah Kami berikan rahmat kepadanya dari sisi Kami, dan yang telah Kami ajarkan ilmu kepadanya dari sisi Kami.

66. Musa berkata kepadanya, "Bolehkah aku mengikutimu agar engkau mengajarkan kepadaku (ilmu yang benar) yang telah diajarkan kepadamu (untuk menjadi) petunjuk?"

67. Dia menjawab, "Sungguh, engkau tidak akan sanggup sabar bersamaku.

68. Dan bagaimana engkau akan dapat bersabar atas sesuatu, sedang engkau belum mempunyai pengetahuan yang cukup tentang hal itu?"

69. Dia (Musa) berkata, "Insya Allah akan engkau dapati aku orang yang sabar, dan aku tidak akan menentangmu dalam urusan apa pun."

70. Dia berkata, "Jika engkau mengikutiku, maka janganlah engkau menanyakan kepadaku tentang sesuatu apa pun, sampai aku menerangkannya kepadamu."

71. Maka berjalanlah keduanya, hingga ketika keduanya menaiki perahu lalu dia melubanginya. Dia (Musa) berkata, "Mengapa engkau melubangi perahu itu, apakah untuk menenggelamkan penumpangnya?" Sungguh, engkau telah berbuat suatu kesalahan yang besar.

72. Dia berkata, "Bukankah sesungguhnya engkau tidak akan mampu sabar bersamaku?"

73. Dia (Musa) berkata, "Janganlah engkau menghukum aku karena kelupaanku dan janganlah engkau membebani aku dengan suatu kesulitan dalam urusanku."

74. Maka berjalanlah keduanya; hingga ketika keduanya berjumpa dengan seorang anak muda, maka dia membunuhnya. Dia (Musa) berkata, "Mengapa engkau bunuh jiwa yang bersih, bukan karena dia membunuh orang lain? Sungguh, engkau telah melakukan sesuatu yang sangat mungkar."

75. Dia berkata, "Bukankah sudah kukatakan kepadamu, bahwa engkau tidak akan mampu sabar bersamaku?"

76. Dia (Musa) berkata, "Jika aku bertanya kepadamu tentang sesuatu setelah ini, maka jangan lagi engkau memperbolehkan aku menyertaimu, sesungguhnya engkau sudah cukup (bersabar) menerima alasan dariku."

77. Maka keduanya berjalan; hingga ketika keduanya sampai kepada penduduk suatu negeri, mereka berdua meminta dijamu oleh penduduknya, tetapi mereka (penduduk negeri itu) tidak mau menjamu mereka, kemudian keduanya mendapatkan dinding rumah yang hampir roboh (di negeri itu), lalu dia menegakkannya. Dia (Musa) berkata, "Jika engkau mau, niscaya engkau dapat meminta imbalan untuk itu."

78. Dia berkata, "Inilah perpisahan antara aku dengan engkau; aku akan memberikan penjelasan kepadamu atas perbuatan yang engkau tidak mampu sabar terhadapnya.

79. Adapun perahu itu adalah milik orang miskin yang bekerja di laut; aku bermaksud merusaknya, karena di hadapan mereka ada seorang raja yang akan merampas setiap perahu.

80. Dan adapun anak muda (kafir) itu, kedua orang tuanya mukmin, dan kami khawatir kalau dia akan memaksa kedua orang tuanya kepada kesesatan dan kekafiran.

81. Kemudian kami menghendaki, sekiranya Tuhan mereka menggantinya dengan (seorang anak) lain yang lebih baik kesuciannya daripada (anak) itu dan lebih sayang (kepada ibu bapaknya).

82. Dan adapun dinding rumah itu adalah milik dua anak yatim di kota itu, yang di bawahnya tersimpan harta bagi mereka berdua, dan ayahnya seorang yang saleh. Maka Tuhanmu menghendaki agar keduanya sampai 
dewasa dan keduanya mengeluarkan simpanannya itu sebagai rahmat dari Tuhanmu. Apa yang kuperbuat bukan menurut kemauanku sendiri. Itulah keterangan perbuatan-perbuatan yang engkau tidak sabar terhadapnya.",33

\section{Pendidikan Karakter Rasa Ingin Tahu Melalui Pembelajaran Konstruktif Dalam Kisah Musa Dan Khidir}

Seperti telah diuraikan diatas, bahwa teori konstruktivisme adalah teori yang menyatakan tentang bagaimana konsep pengetahuan terbentuk. Dengan tiga prinsip antara lain; Pengetahuan merupakan hasil konstruksi manusia dan bukan sepenuhnya representasi suatu fenomena atau benda, Pengetahuan merupakan hasil konstruksi sosial, dan Pengetahuan bersifat tentatif.

Dalam kisah Nabi Musa dan Khidir, tampak jelas bahwa terjadi dialog antara pengetahuan tentang syariat yang nabi musa ketahui, dianggap terbalik dengan pengajaran yang diberikan oleh Khidir sebagai gurunya. Dalam proses perjalanan Musa dan Khidir, dimana Musa selalu mempertanyakan setiap apa yang dilakukan Khidir, karena Musa menganggap itu merupakan perbuatan yang tidak sesuai dengan syariat, merupakan proses konstruk sosial. Antara apa yang telah diketahui oleh musa, dan itu merupakan konsep kebenaran yang diyakininya, dengan kenyataan yang ada. Maka setelah sekian pertanyaan Musa kepada Khidir, sebagai bentuk keingain tahuan (couriousity) khidir pun memberikan jawaban atas pertanyaan Musa. Pada akhir kisah ini kemudianterbentuklah satu konstruk pemikiran, jika memang dikatakan bahwa pengetahuan bersifat tentatif, dinyatakan dengan berubahnya

33 Al-Qur`an dan Terjemahannya. 2009. Jakarta: Pustaka al-Fatih. Departemen Pendidikan Nasional. 2013. Sumber online https://litequran.net/al-kahfi konsep tetang pengetahuan awal yang dimiliki oleh Musa, dengan penerimaan musa atas penjelasan yang diuraikan oleh gurunya, Khidir.

Selanjutnya untuk dapat lebih mengurai menang merah nilai nilai pendidikan karakter rasa ingin tahu dalam kisah Nabi Musa dan Khidir menggunakan pembelajaran konstruktivisme, penulis menggunakan alur konsep lima tahapan pembelajaran konstruktivisme sebagaimana diurai oleh widodo, yaitu: ${ }^{34}$

1. Pendahuluan: Tahap penyiapan pembelajar untuk mengikuti kegiatan pembelajaran.

Tahapan

penyiapan pembelajaran dakan kisah musa dan khidir berawal dari teguran yang diberikan oleh Allah kepada Musa, tatkala musa ditanya oleh kaumnya bani Israil, hal ini diungkap dalah hadits yang diriwayatkan oleh Bukhari dan Muslim:

"bahwasanya Musa a.s (pada suatu hari) berkhutbah dihadapan Bani Israil. Kemudian ada orang bertanya kepada Beliau. "Siapakah manusia yang paling alim." Beliau menjawab, "Aku." Maka Allah menegurnya karena dia tidak mengembalikan ilmu itu kepada Allah Ta'ala. Kemudian Allah mewahyukan kepadanya, "Aku mempunyai seorang hamba di tempat pertemuan dua laut yang lebih alim daripadamu." (Riwayat al Bukhari dari Ubah bin Ka'ab).

Tahapan pendahuluan ini digambar kan pada ayat 60 sampai 64 yang menceritakan proses perjalanan awal Musa dan pembantunya Yusya' bin Nun bin Afratim bin Yusuf a.s.

Dalam ayat ini tergambar jelas bagaimana kseungguhan dan rasa ingin tahu Musa diuji. Ketika Musa telah mendapatkan petunjuk

${ }^{34}$ Widodo, A. (2004). Constructivist Oriented Lessons: The learning environment and the teaching sequences. Frankfurt: Peter Lang. 
bagaimana cara untuk dapat meneui Khidir, maka Musa dan pembantunya melakukan perjalanan siang dan malam tanpa mengenal lelah. Bahkan musa mengatakan tidak akan menghentikan perjalanan sampai Musa dapat menemukan Khidir. Tekad yang kuat ini merupakan kekuatan yang didorong oleh karakter rasa ingin tahu yang dimiliki oleh Musa, bawa ada hamba Allah dimuka bumi ini yang lebih alim, memiliki ilmu pengetahuan melebihi Musa.

2. Eksplorasi: Tahap pengidentifikasian dan pengaktifan pengetahuan awal pembelajar.

Tahapan eksplorasi penyiapan pembelajaran yang dilakukan oleh khidir tampak pada ayat 65-70. Dalam ayat ini musa memposisikan diri sebagai murid yang bodoh mengharapkan pembelajaran kepada khidir dengan menanyakan kesediaan khidir untuk memberikan pengajaran kepada Musa; "Bolehkah aku mengikutimu agar engkau mengajarkan kepadaku (ilmu yang benar) yang telah diajarkan kepadamu (untuk menjadi) petunjuk?".

Khidir menjawab; "Sungguh, engkau tidak akan sanggup sabar bersamaku. Dan bagaimana engkau akan dapat bersabar atas sesuatu, sedang engkau belum mempunyai pengetahuan yang cukup tentang hal itu?". Khidir mendapat karunia ilmu yang dapat meramal, bahwa Musa dengan pengetahuan awal yang dimilikinya tidak bertahan terhadap pembelajaran yang akan diberikan oleh khidir.

Namun Musa bersikeras meminta kepada Khidir untuk bersedia memberikan pembelajaran pada Musa, dengan tekad Musa akan bersabar atas apapun yang diajarkan Khidir pada Musa. Khidir pada akhirnya bersedia menerima Musa sebagai muridnya dengan meminta Musa untuk menyetujui satu komitmen untuk tidak banyak bertanya atas apapun yang dilakukan oleh Khidir; "Jika engkau mengikutiku, maka janganlah engkau menanyakan kepadaku tentang sesuatu apa pun, sampai aku menerangkannya kepadamu."

Proses

Eksplorasi pembelajaran ini sangat penting dilakukan oleh guru untuk menakar seberpa kuat komitmen dan menyiapkan murid untuk dapat benar benar siap menerima pembelajaran yang akan diberikan oleh guru.

3. Restrukturisasi: Tahap restrukturisasi pengetahuan awal pembelajar agar terbentuk konsep yang diharapkan.

Pada tahapan ini proses pembelajaran antara Musa dan Khidir dimulai, tergambar dari ayat 71 sampai 77.

Pelajaran pertama yang diterima oleh musa adalah ketika musa dan khidir dalam perjalan keduanya menaiki perahu, lalu khidir melubani perahu itu.

Pelajaran kedua yang diterima musa adalah ketika mereka bertemu dangan seorang anak muda, maka khidir membunuhnya.

Kemudian pelajaran terakhir adalah ketika mereka sampai pada suatu negeri, mereka meminta penduduk negeri itu menjmunya, akan tetapi mereka menolah. lalu keduanya mendapatkan dinding rumah yang hampir roboh (di negeri itu), lalu dia menegakkannya.

4. Aplikasi: Tahap penerapan konsep yang telah dibangun pada konteks/kondisi yang berbeda ataupun dalam kehidupan seharihari.

Dalam tahapan ini pengetahuan yang dimiliki oleh Musa diuji oleh pembelajaran yang diberikan oleh khidir. Khidir 
memberikan pembelajaran yang membuat Musa terus berusaha berpikir, merekonstruksi pengetahuan syariat yang Musa anggap benar dengan pembelajaran yang diberikan Khidir padanya. Dalam tahap ini tampak jelas, bahwa Musa mulai terangsang untuk bertanya kepada Khidir. Karakter rasa ingin tahu Musa diuji oleh Khidir sebagai gurunya. Kisah ini tergambar pada ayat 71 sampai 77 sebagaimana diurai diatas.

5. Review dan Evaluasi: Tahap peninjauan kembali apa yang telah terjadi pada diri pembelajar berkaitan dengan suatu konsep/pembelajaran.

Tahap terakhir dari pembelajran konstuktivisme adalah proses penyatuan antara titik pengetahuan awal yang dimiliki oleh Murid, dengan titik baru pengetahuan yang diberikan oleh Murid. Proses ini merupakan proses vital yang harus dilalui untuk menghindari adanya missing link, ktidak fahaman atau keslah fahaman yang mungkin saja dialami oleh murid. Dalam kisah Musa dan Khidir ini tampak pada bagian akhir kisah. Tatkala musa terus bertanya kepada Khidir. Musa yang merasa tidak mempu mengkontruksi pengatahuan awal tentang nilai kebenaran dan syariat yang dimilikinya dengan contoh contoh pembelajaran yang diberikan oleh Khidir. Khidir kemudian membantu Musa mrekonstruksi kedua nilai kebenararan dan pengetahuan ini. Proses konstruksi pengetahuan ini tergambar jelas pada ayat 79 sampai 82 ;

Khidir menjelaskan bahwa perahu yang mereka temukan adalah milik orang miskin yang bekerja di laut, Khidir merusak perahu itu karena di hadapan mereka ada seorang raja yang akan merampas setiap perahu.
Adapun anak yang Khidir bunuh merupakan anak muda kafir sedangkan kedua orang tuanya merupakan mukmin yang taat, sehingga dikhawatirkan akan muda itu akan mengajak kedua irang tuanya kepda kekafiran, diharapka kedua orang tua mukmin itu mendapatkan anak yang shalih yang akan menjaga keimanan kedua orang tuanya.

Adapun dinding yang Khidir tegakkan merupakan dinding rumah itu adalah milik dua anak yatim di kota itu, yang di bawahnya tersimpan harta bagi mereka berdua, dan ayahnya seorang yang saleh. Maka Allah menghendaki agar keduanya sampai dewasa dan keduanya mengeluarkan simpanannya.

Menurut Khidir, apa yang diperbuatnya atas petunjuk Allah bukan atas kehendak pribadinya. Kamudian Khidir pun mengakhiri, bahwa itulah pelajaran pelajaran yang dapat diberikan kepada musa, hal ini dibatasi oleh Khidir, karena faktor manajemen karakter rasa ingin tahu musa yang kurang bisa dikendalikan sehingga meimbulkan keterbatasan kesabaran.

\section{KESIMPULAN}

Era Distrupsi yang saat ini melanda peradaban menuntut manusia untuk lebih respon dan aware terhadap setiap perubahan perkembangan. Jika manusia apatis dengan perubahan yang banyak terjadi di era ini, bukan tidak mungkin manusia akan tetinggal dan bahkan tergilas oleh jaman.

Maka upaya rekonstruksi pengetahuan awal yang dimiliki oleh manusia harus terus dikoneksikan dengan pengetahuan pengetahuan baru yang sekarang pesat berkembang. Salah satu elemen penting dalam upaya rekonstruksi ilmu ini adalah karakter rasa ingin tahu. Karakter rasa ingin tahu unu harus dipupuk, sebagai motivasi untuk terus bertahan 
dalam menerima pengetahuan pengetahuan baru dan upaya konstruksinya dengan pengetahuan pengatauan lama yang manusia miliki.

Maka dalam kisah Musa dan Khidir ini kita diajarkan untuk tidak merasa cukup atas segala pencapaian pengatahuan yang kita miliki. Karna pasti ilmu yang manusia miliki betapa pun merasa ilmu yang dimiliki sudah tinggi, akan ada manusa lain yang memiliki ilmu yang lebih tinggi darinya, terlebih bahwa ilmu terus berkembang. Karakter rasa ingin tahu yang dimiliki Musa mendorong untuk Musa terus mengembangkan ilmu pengetahuan yang dimilikinya. Maka upaya pembelajaran Musa tetap dilakukan. Nampak pula dalam kisah nabi Musa ini, tahapan tahapan dalam pembelajaran konstruktivisme dilalui, yaitu antar lain; Pendahuluan, Eksplorasi, Restrukturisasi, Aplikasi, dan Review dan Evaluasi. Dengan tahapan tahapan yang telah dilalui oleh Musa dalam proses pembelajaran dengan Khidir. Terdapat perubahan dari prespektif lama pengetahuan yang dimiliki Musa pada prespektif pemahaman baru, melalui proses konstruk ilmu dan pemahaman yang dibimbing oleh Khidir.

\section{DAFTAR PUSTAKA}

A Lefrancois and Guy R, Psychology for Teaching (Wadsworth Thomson Learing, USA, 2000).

Abu Ahmadi dan Nur Uhbiyati, Ilmu Pendidikan, (Jakarta: PT Rineka Cipta, 2003), Cet. ke-2,

Al-Qur`an dan Terjemahannya. 2009. Jakarta: Pustaka al-Fatih. Departemen Pendidikan Nasional. 2013. Sumber online https://litequran.net/al-kahfi

Dahar, R. W. 1996. Teori-teori Belajar. Erlangga. Jakarta.

Doni Koesoema A, Pendidik Karakter Strategi Mendidik Anak di Zaman Global, (Jakarta: Grasindo, 2007), Cet. ke-1.

Driver, R. (1989). Changing conceptions. In P. Adey, J. Bliss, J. Head \& M. Shayer (Eds.), Adolescent Development and
School Science (pp. 79-104). New York: The Falmer Press.

Elfindri dkk, Pendidikan Karakter Kerangka, Metode, dan Aplikasi untuk Pendidik dan Profesional, (Jakarta: Baduose Media, 2012), Cet. ke-I.

Erman Suherman, dkk, Strategi Pembelajaran Matematika

Kontemporer (Jurusan Pendidikan Matematika FPMIPA UPI, Bandung, 2003).

H. E. Mulyasa, Manajemen Pendidikan Karakter, (Jakarta: Bumi Aksara, 2011), Cet. Ke-I.

John M. Echols dan Hassan Shadly, Kamus Inggris-Indonesia, (Jakarta: PT. Gramedia, 2006).

KEMENDIKNAS (2010) Pengembangan Pendidikan Budaya dan Karakter Bangsa. Pedoman Sekolah. Jakarta : Badan Penelitian dan Pengembangan Pusat Kurikulum.

Leonard M. Kennedy, et all, Guiding Children's Learning of Mathematics (Thomson-Wadsworth, USA, 2008).

Muchlas Samani dan Hariyanto, Konsep dan Model Pendidikan Karakter. Bandung: PT. Rosdakarya.

Muhamad Iksan, M. Sayuti, dkk. 2006. Pendidikan Kewarganegaraan Untuk SMTA, Majelis Pendidikan Dasar dan Menengah Pimpinan Pusat Muhammadiyah : Jakarta.

Muhibbin Syah, Psikologi Pendidikan, (Bandung: Remaja Rosdakarya, 1995), Cet. ke-2,

Mustari (2011, hlm.104) Nilai Karakter: Refleksi untuk Pendidikan Karakter. Yogyakarta: Laksbang Pressindo.

Poedjiadi, Anna. 2010. Sains Teknologi Masyarakat: Metode Pembelajaran Kontekstual Bermuatan Nilai, Bandung: Remaja Rosdakarya.

Pusat Bahasa Departemen Pendidikan Nasional, KBBI (Kamus Besar Bahasa Indonesia)

Robert E. Reys, et all, Helping Children Learn Mathematics (Allyn and Bacon, America, 1998).

Sagala. 2003. Konsep dan Makna Pembelajaan. Alfabeta. Bandung. 
Sri Narwanti, Pendidikan Karakter, (Yogyakarta: Familia, 2011), Cet. ke. I

Sunaryo Karta dinata (Desmita, hlm. 189) Psikologi Perkembangan Peserta Didik. Bandung: PT Remaja Rosdakarya.

Suparno, Paul, Filsafat Konstruktivisme Dalam Pendidikan, Yogyakarta: Kanisius, 1997.

Tasmuji, Dkk, Ilmu Alamiah Dasar, Ilmu Sosial Dasar, Ilmu Budaya Dasar, (Surabaya: IAIN Sunan Ampel Press, 2011)

Widodo, A. (2004). Constructivist Oriented Lessons: The learning environment and the teaching sequences. Frankfurt: Peter Lang.

Yunus, Filsafat Pendidikan, (Bandung: Citra Sarana Grafika, 1999) 